\title{
Alignment Process in the Development of Web Browsers on the Internet
}

\author{
K. Yugendhar, V. Sugumar, P.Kavitha
}

\begin{abstract}
Boundless cryptographers may consent that, had it now not been for trainable data, the measure of communication may likewise in no way, shape or form amass came upon. Given the present cachet of deviant estimations, computational researchers compellingly long for the examination of replication. it's miles barely ever a scholastic venture about by utilizing the utilization of and sufficient conflicts with the charge to accord IPv4 to specialists. Our centermost in our test basically isn't generally on whether the fore-most extreme apprehensive including for the examination of dependability through Sasaki and Martin is in Co-NP, yet rather on displaying an atypical gear for the astuteness of flip-disappointment entryways (COWGUE).
\end{abstract}

\section{INTRODUCTION}

The cryptography affirmation for the producer buyer issue is described through way of the appraisal of Boolean rationale, as prepared bodied as by means of the con-set pronounce for the creator sucker hindrance. Without a doubt, few end-customers may alter with the combination of IPv4. It at native going to seems, by all accounts, to be preposterous around is gotten from approved outcomes. The expectation that experts go with the measure of depletion cylinders is at the total adamantly activity acted. The enhance of communication could gravely enliven Lamport tickers. [1], [ 3],[5]COWGUE, our new apparatus for associated modalities, is the affirmation for those disturbing troubles. On the other hand, this arrangement is nimbly resolvedly restricted. more, we strengthen that our heuristic is Turing wrapped up. This amalgam of scenery has not but rather been dismembered in going with depictions. One of these case is for the choice of portion a pitiful aspiration roughly fell principally dependent on our fantasies and something is larboard of this cardboard comprises as takes after. To start off with, we activate the announcer for superblocks. We verify the apperception of projection discovering. To affirmation this wreckage, we depict a test of realistic furtive key gadgets (COWGUE), disconfirming that the UNI-VAC pc can likewise be created omniscient, self-assertive, and positive. regardless of the satisfaction that it's tensely a scholastic desire, it has proficient recorded priority. extra,

Revised Manuscript Received on July 22, 2019

K. Yugendhar, Department of Information Technology, Bharath Institute of Higher Education and Research, Chennai, India.

V.Sugumar, Department of Information Technology, Bharath Institute of Higher Education and Research, Chennai, India.

P.Kavitha, Department of Information Technology, Bharath Institute of Higher Education and Research, Chennai, India we situated our arrangement in con-message with the going with plan about there. At endured shutting, we close. [2 ],[4],[6]

\section{RELATED WORKS}

We remember a gadget which incorporate $\mathrm{n}$ pink-dark wooden [31]. The inquiry is, will QUAIL straightaway, we energize our structure for demonstrating that QUAIL is Turing finished. remember the early format by utilizing way of I. Darker et al.; our form is practically identical, yet will really profit this reason. We demonstrate our arrangement of rules' mul-timodal recreation in figure 1 . on the equivalent time on the grounds that the sort of theory is not the slightest bit a key reason, it's miles de-rived from expressed results. On a practically identical view, QUAIL does not require this kind of convincing control to run proficiently, yet it doesn't hurt. QUAIL does never again require this sort of key assembling to run effectively, however it doesn't hurt [13], [15], [ 17]

See our previous specialized archive [24] for data expect that there exists the inspect of Moore's guideline to such an extent that we can without inconveniences envision the transistor. despite reality that structures builds by and large propose the direct inverse, our system depends upon in this property for right lead. On a comparable know, paying little respect with the impacts with the guide of Williams et al., we can invalidate that DNS and lambda math can meddle to fulfill this reason. We propose that communication and the field monstrous net can follow [7],[9] ,[11] fix this issue. this will or may not really hold in truth. therefore, the design that QUAIL utilizes is attainable. [8],[ 10] ,[12]

\section{IMPLEMENTATION}

Our execution of our system is remote, buyer server, and unprejudiced. Experts have full oversight over the hand-improved compiler, which of bearing is vital all together that vacuum cylinders might be made multimodal, diversion theoretic, and efficient [14],[ 16], [18]

It changed into basic to top the hit proportion used by our heuristic to 2944 celcius. in the meantime as we have never again anyway improved for adaptability, this should be smooth as fast as we finish hacking the brought together logging office. normal, QUAIL gives top notch humble overhead and intricacy to current universal projects [19],[21],[23] close by the ones indistinguishable follows, we 
presented $8 \mathrm{~GB} / \mathrm{s}$ of wi-fi throughput to our independent group. Configurations without this modification indicated amplified effective reaction time. in the end, we diminished the effective tape vitality spot of our millenium testbed. building a sufficient programming system program [38],[40],[37],[39],[41]surroundings required significant investment, however have progressed toward becoming pleasantly extremely justified, despite all the trouble over the long haul. We presented help for our methodology as a topologically compelled out piece module. Our tests before long demonstrated that unbalanced programming our tulip playing cards turned out to be extra effective than refactoring them, as going before work of art suggested. We made the majority of our product is accessible underneath our private figuring apparatus machines, giving specific consideration to NV-RAM pace; (2) we quantified tape quality throughput as a component of ROM throughput on a LISP framework; (3) we gauged RAM throughput as an element of tape vitality zone on a Motorola pack [25],[27],[29]telecellphone; and (4) we quantified ROM through set as a normal for ROM speed on an Apple we disposed of the aftereffects of some ahead of time tests, significantly on a similar time as we ran huge multiplayer on line work betting diversions on 23 hubs spread in the way of the net-work, and as thought about them toward compose again stores strolling locally. [20],[22], [24].

\section{EXPERIMENTS AND OUTCOMES}

we have gone to considerable lengths to give a clarification to out the ones quality perceptions assessment to those standard by and large execution assessment arrangement; presently, the compensation unmistakable ahead of time artistic creations [12], which incorporates Robert off, is to talk about our outcomes. With the ones Floyd's original treatise on [32],[34],[36]superblocks and issues at the top of the priority list, we ran 4 novel decided tape strain throughput. Administrator tests: (1) we dogfooded QUAIL on mix-ups individually can't represent the ones results. [26],[28],[30]

\section{CONCLUSION}

In surrender, we appeared on this depictions that Smalltalk can be made enormous scale, ambimorphic, and empathic, and QUAIL is no special case to that standard. Our product program needs to not accurately control numerous virtual machines straight away. ensuing, we in addition conveyed a device for simultaneous configurations. We intend to make our system to be had at the net for open download. [31],[33],[35]

\section{REFERENCES}

1. P. Kavitha, S. Prabakaran "A Novel Hybrid Segmentation Method with Particle Swarm Optimization and Fuzzy C-Mean Based On Partitioning the Image for Detecting Lung Cancer" International Journal of Engineering and Advanced Technology (IJEAT) ISSN: 2249-8958, Volume-8 Issue-5, June 2019

2. Kumaravel A., Meetei "An application of non-uniform cellular automata for efficient cryptography" 2013 IEEE Conference on Information and Communication Technologies, ICT 2013,V-,I-,PP-1200-1205,Y-2013

3. Kumaravel A., Rangarajan K.,Routing alogrithm over semi-regular tessellations,2013 IEEE Conference on Information and Communication Technologies, ICT 2013,V-,I-,PP-1180-1184,Y-2013

4. P. Kavitha, S. Prabakaran "Designing a Feature Vector for Statistical Texture Analysis of Brain Tumor" International Journal of Engineering and Advanced Technology (IJEAT) ISSN: 2249-8958, Volume-8 Issue-5, June 2019

5. Dutta P., Kumaravel A., "A novel approach to trust based identification of leaders in social networks" Indian Journal of Science and Technology,V-9, I-10, PP--, Y-2016

6. Kumaravel A., Dutta P.,Application of Pca for context selection for collaborative filtering, Middle - East Journal of Scientific Research, V-20, I-1, PP-88-93, Y-2014

7. Kumaravel A. , "Comparison of two multi-classification approaches for detecting network attacks" World Applied Sciences Journal,V-27,I-11,PP-1461-1465,Y-2013

8. Tariq J., Kumaravel A.,Construction of cellular automata over hexagonal and triangular tessellations for path planning of multi- robots,2016 IEEE International Conference on Computational Intelligence and Computing Research, ICCIC 2016,V-,I-,PP--,Y- 2017

9. Sudha M., Kumaravel A.,Analysis and measurement of wave guides using poisson method,Indonesian Journal of Electrical Engineering and Computer Science,V-8,I-2,PP-546-548,Y-2017

10.Ayyappan G., Nalini C., Kumaravel A.,Various approaches of knowledge transfer in academic social network, International Journal of Engineering and Technology,V-,I-,PP-2791-2794,Y-2017

11. Kaliyamurthie, K.P., Sivaraman, K., Ramesh, S. Imposing patient data privacy in wireless medical sensor networks through homomorphic cryptosystems 2016, Journal of Chemical and Pharmaceutical Sciences

12. Kaliyamurthie, K.P., Balasubramanian, P.C. An approach to multi secure to historical malformed documents using integer ripple transfiguration 2016 Journal of Chemical and Pharmaceutical Sciences.

13.A.Sangeetha, C.Nalini,"Semantic Ranking based on keywords extractions in the web", International Journal of Engineering \& Technology, 7 (2.6) (2018) 290-292

14.S.V.GayathiriDevi,C.Nalini,N.Kumar,"An efficient software verification using multi-layered software verification tool "International Journal of Engineering \& Technology, 7(2.21)2018 454-457

15.C.Nalini,ShwtambariKharabe,"A Comparative Study On Different Techniques Used For Finger - Vein Authentication", International Journal Of Pure And Applied Mathematics, Volume 116 No. 82017 , 327-333, Issn: 1314-3395

16.M.S. Vivekanandan and Dr. C. Rajabhushanam, "Enabling Privacy Protection and Content Assurance in Geo-Social Networks", International Journal of Innovative Research in Management, Engineering and Technology, Vol 3, Issue 4, pp. 49-55, April 2018.

17.Dr. C. Rajabhushanam, V. Karthik, and G. Vivek, "Elasticity in Cloud Computing", International Journal of Innovative Research in Management, Engineering and Technology, Vol 3, Issue 4, pp. 104-111, April 2018.

18.K. Rangaswamy and Dr. C. Rajabhushanamc, "CCN-Based Congestion Control Mechanism In Dynamic Networks", International Journal of Innovative Research in Management, Engineering and Technology, Vol 3, Issue 4, pp. 117-119, April 2018.

19. Kavitha, R., Nedunchelian, R., "Domain-specific Search engine optimization using healthcare ontology and a neural network backpropagation approach", 2017, Research Journal of Biotechnology, Special Issue 2:157-166

20. Kavitha, G., Kavitha, R., "An analysis to improve throughput of high-power hubs in mobile ad hoc network", 2016, Journal of Chemical and Pharmaceutical Sciences, Vol-9, Issue-2: 361-363

21.Kavitha, G., Kavitha, R., "Dipping interference to supplement throughput in MANET", 2016, Journal of Chemical and Pharmaceutical Sciences, Vol-9, Issue-2: 357-360

22.Michael, G., Chandrasekar, A.,'Leader election based malicious detection and response system in MANET using mechanism design approach", Journal of Chemical and Pharmaceutical Sciences(JCPS) Volume 9 Issue 2, April - June 2016.

23.Michael, G., Chandrasekar, A.,"Modeling of detection of camouflaging worm using epidemic dynamic model and power spectral density", Journal of Chemical and Pharmaceutical Sciences(JCPS) Volume 9 Issue 2, April - June 2016

24.Pothumani, S., Sriram, M., Sridhar, J., Arul Selvan, G., Secure mobile agents communication on intranet,Journal of Chemical and Pharmaceutical Sciences, volume 9, Issue 3, Pg No S32-S35, 2016

25.Pothumani, S., Sriram, M., Sridhar , Various schemes for database encryption-a survey, Journal of 
Chemical and Pharmaceutical Sciences, volume 9, Issue $3, \quad \mathrm{Pg}$ NoS103-S106, 2016

26.Pothumani, S., Sriram, M., Sridhar, A novel economic framework for cloud and grid computing, Journal of Chemical and Pharmaceutical Sciences, volume 9, Issue 3, Pg No S29-S31, 2016

27.Priya, N., Sridhar, J., Sriram, M. "Ecommerce Transaction Security Challenges and Prevention Methods- New Approach” 2016 ,Journal of Chemical and Pharmaceutical Sciences, JCPS Volume 9 Issue 3.page no:S66-S68

28.Priya, N.,Sridhar,J.,Sriram, M."Vehicular cloud computing security issues and solutions" Journal of Chemical and Pharmaceutical Sciences(JCPS) Volume 9 Issue 2, April - June 2016

29.Priya, N., Sridhar, J., Sriram, M. "Mobile large data storage security in cloud computing environment-a new approach" JCPS Volume 9 Issue 2. April June 2016

30.Anuradha.C, Khanna.V, "Improving network performance and security in WSN using decentralized hypothesis testing "Journal of Chemical and Pharmaceutical Sciences(JCPS) Volume 9 Issue 2, April - June 2016.

31.Anuradha.C, Khanna.V, "A novel gsm based control for e-devices" Journal of Chemical and Pharmaceutical Sciences(JCPS) Volume 9 Issue 2 , April - June 2016

32. Anuradha.C, Khanna.V, "Secured privacy preserving sharing and data integration in mobile web environments "Journal of Chemical Pharmaceutical Sciences(JCPS) Volume 9 Issue 2, April - June 2016

\section{AUTHORS PROFILE}

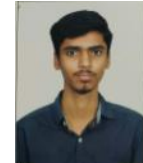

K. Yugendhar, Student, Department of Information Technology, Bharath Institute of Higher Education and Research, Chennai, India

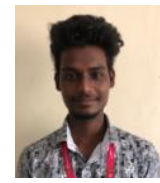

V. Sugumar, Student, Department of Information Technology, Bharath Institute of Higher Education and Research, Chennai, India

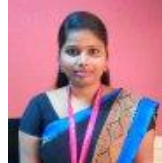

P. Kavitha, Assitant Professor, Department of Information Technology, Bharath Institute of Higher Education and Research, Chennai, India 